\title{
'Today a Christian Nation, Tomorrow a Muslim Nation': a Defence of Rotating State Religions
}

\author{
Bouke de Vries ${ }^{1}$ (D) \\ Accepted: 24 November 2020 / Published online: 7 December 2020 \\ (C) The Author(s) 2020
}

\begin{abstract}
In more than $20 \%$ of countries, a single religion is recognized in the constitution. This article argues that there are good reasons for opposing such 'mono-recognition' as it fails to show due concern to members of constitutionally unrecognized (non-extremist) religions. Yet rather than opting for disestablishment as Sweden did in 2000, I show that there may be a better alternative in many cases: To constitutionally recognize a variety of religions. After distinguishing synchronic forms of plural recognition whereby multiple religions are constitutionally recognized simultaneously from diachronic forms whereby state religions are rotated, I defend the latter option. On this approach, a multi-religious state might have Catholicism as the state religion during the first part of the year, then Islam, then Judaism, and so on, whereby I argue that there ought to be differences in the amount of time that religions are recognized depending on differences in the strength of their claims to constitutional recognition. Besides being fairer than mono-recognition and synchronic plural recognition, I show that when some religious groups are marginalized, diachronic plural recognition has significant advantages over non-recognition of any religion as constitutionally recognizing these groups' religions sends valuable signals that their members belong to society.
\end{abstract}

Keywords State religions · Religious establishment $\cdot$ State church $\cdot$ Multiculturalism $\cdot$ Christianity $\cdot$ Islam $\cdot$ Judaism $\cdot$ Hinduism

\section{Introduction}

According to a 2017 report by the Pew Research Center (2017), more than $20 \%$ of countries recognizes a single religion in their constitution. For example, section 4 of the Danish constitution states that "the Evangelical-Lutheran Church is the Danish People's Church"; article 2 of the Afghan constitution that "The sacred religion of Islam is the religion of the

Bouke de Vries

bouke.devries@umu.se

1 Department of Historical, Philosophical and Religious Studies, Umeå University, Umeå, Sweden 
Islamic Republic of Afghanistan"; and article 43 of the Cambodian constitution that "Buddhism shall be the State religion". Constitutional recognition of a religion, or what I will interchangeably refer to as 'religious establishment' or the presence of a 'state religion', is often accompanied by forms of public support for the recognized religion (e.g. tax exemptions, payments of clergy salaries, guaranteed representation in legislative assemblies, subsidies for religious education, subsidies for the maintenance of places of worship) and sometimes also by discrimination against, and oppression of, ${ }^{1}$ individuals who do not adhere to the recognized religion (think of labor market discrimination and of laws that proscribe public endorsements of non-recognized religions). None of these things are inherent to religious establishment, however, as it is possible to have largely if not wholly symbolic forms of establishment that confer few if any tangible benefits upon recognized religions and that do not impose any significant disadvantages upon non-recognized religions, which some scholars believe can be found in various contemporary liberal democracies (Maclure and Taylor 2011, 26).

In this article, my aim is to consider whether there are forms of religious establishment that can be morally justified and, if so, which ones. This question is a timely one as existing systems of religious establishment have become controversial within many countries. In the UK, for instance, organizations such as Humanists UK and the National Secular Society (NSS) have been campaigning for the disestablishment of the Church of England, with some surveys suggesting that a majority of British people are now supporting their cause (Kellner 2013). In Iceland, a 2015 poll revealed that $55 \%$ of the population wanted the state's ties with the Evangelical Lutheran Church to be cut completely (Ingolfsson 2015), whilst a 2013 poll in Costa Rica, where Catholicism is the state religion, found that $47 \%$ of its population wanted a wholly secular state (América Economía 2013). A similar trend can be witnessed in academia where a growing chorus of normative theorists has reservations about religious establishment (e.g. Cohen 2013; Nussbaum 2011, 43-44; Patten 2014, 113).

In what follows, I join this chorus as far as the constitutional recognition of a single religion or what I refer to as 'mono-recognition' is concerned. As I argue, the problem with this type of recognition is that it fails to show due concern to the interests members of constitutionally unrecognized (non-extremist) religions. Yet rather than opting for disestablishment as Sweden did in 2000, I show that there may be a better alternative in many cases: To constitutionally recognize a variety of religions. After distinguishing synchronic forms of plural recognition whereby multiple religions are constitutionally recognized simultaneously from diachronic forms whereby state religions are rotated, I defend the latter option. On this approach, a multireligious state might have Catholicism as the state religion during the first part of the year, then Islam, then Judaism, and so on, whereby I argue that there ought to be differences in the amount of time that religions are recognized depending on differences in the strength of their claims to constitutional recognition. Besides being fairer than mono-recognition and synchronic plural recognition, I show that when some religious groups are marginalized, diachronic plural recognition has significant advantages over non-recognition of any religion as constitutionally recognizing these groups' religions sends valuable signals that their members belong to society.

\footnotetext{
${ }^{1}$ One might think, for instance, of the oppression suffered by the Baha'I in Iran and AlArqam Muslims in Malesia. See Pew Research Center (2017).
} 


\section{Some Preliminaries}

Before vindicating these claims, a few preliminary comments are in order.

\subsection{Largely if Not Wholly Symbolic Recognition}

The first one is that, throughout this article, my focus is on cases where the constitutional recognition that is granted to particular religions is largely if not wholly symbolic. One thing this means is that no special legal requirements are imposed upon the ways in which constitutionally recognized religions govern themselves. For example, even if Catholicism is the state religion, it would be impermissible for states to force the Catholic Church within their country to ordain women as priests. Neither would it be permissible for them to make changes to a religion's internal laws conditional upon parliamentary approval, which is a requirement to which the Church of England is subject (Sandberg 2011, 63). The reason for focusing upon forms of religious establishment that do not impose such requirements is that ones that do are especially controversial as they impose significant constraints upon people's associational and religious liberties. Since my aim here is to consider whether there are defensible forms of religious establishment simpliciter as opposed to considering whether especially controversial forms of religious establishment can be vindicated, focusing upon largely if not wholly symbolic forms of religious establishment helps me to achieve this aim.

Another feature of largely if not wholly symbolic religious establishment that I should highlight is that citizens who do not adhere to constitutionally recognized religion(s) have equal basic rights and liberties, including freedoms of conscience, speech, and association; rights to private property; and rights to political participation. For states to deny such rights and liberties to this group would be unacceptable as it would violate fundamental principles of justice by denying people the opportunity to live minimally decent and free lives. At the same time, largely symbolic religious establishment does not rule out that states grant certain tangible benefits to constitutionally recognized religions that are refused to other religions. Such benefits may take the form of non-basic legal rights, as when leaders of state religions are entitled to participate in state events such as parliamentary inaugurations and state funerals. However, they might also be financial as long as the expenditures that are made are not too high (as they would be when, say, a state funded the entire construction of a modern-day cathedral, which would raise serious distributive justice concerns, but not necessarily when it simply subsidized the maintenance of places of worship or the salaries of clerics). ${ }^{2}$ In defending diachronic plural recognition, I remain non-committal on whether any largely symbolic forms of religious establishment are justifiable or whether only wholly symbolical forms are, i.e. forms whereby the only privilege enjoyed by state religions is that they are recognized in the constitution.

\subsection{Compatibility with Liberal Democracy}

Another assumption that I make in this article, and this brings me to the second comment, is that any religions that are constitutionally recognized are compatible with liberal-democratic politico-legal institutions as I take moderate denominations of e.g. Christianity, Islam, and Judaism to be. (I will interchangeably refer to such religions as 'liberal democracy-compatible'

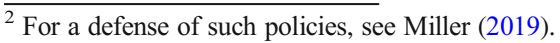


or 'non-extremist'.) Such compatibility exists when the recognized religions respect principles and rights that are central to the functioning of liberal democracies, including the rule of law; civic equality; freedoms of conscience, speech, and association; rights to private property, and rights to political participation. For states to constitutionally recognize religions that do not fit this bill, such as Wahhabism, is deeply problematic symbolically as it puts religions upon a pedestal that oppose the very essentials of a just society, apart from the fact that it risks emboldening individuals with extremist sympathies (cf. Waldron 2014).

\subsection{Secular Comprehensive Doctrines}

The third comment is that I am not precluding the possibility that any constitutional recognition that is granted to religions might need to be extended to (liberal democracy-compatible) secular comprehensive doctrines such as Humanism and Confucianism. Whether this is the case will depend on whether religions have features that render it morally permissible, if not required, to treat them differently in this area. Whilst it is often assumed that they do, identifying such features turns out to be difficult. To see this, it ought to be noted that, like religions, secular comprehensive doctrines can be an important component of people's identity; imbue their existence with meaning; provide them with moral guidance across various domains of life; and render them vulnerable to discrimination and oppression. Since an indepth discussion of this issue would take us too far afield, ${ }^{3}$ I will not try to settle it here.

\section{Diachronic Plural Recognition vs Mono-Recognition}

With these qualifications in place, let us consider why it is that many states have strong reasons even if not always decisive ones ${ }^{4}$ - for adopting a system of diachronic plural recognition, i.e. a system whereby state religions are rotated. To do so, I want to look in this section at the reasons for favoring diachronic plural recognition over the constitutional recognition of a single religion or what I have termed 'mono-recognition'. In examining these reasons, we will also come across some important reasons for favoring diachronic plural recognition over synchronic plural recognition or the simultaneous constitutional recognition of multiple religions (more reasons for favoring this particular type of plural recognition will be discussed later in this article).

The main advantage of diachronic plural recognition over mono-recognition, I believe, is that it is fairer by not giving any religion a monopoly on constitutional recognition. Now defenders of mono-recognition might challenge that mono-recognition is less fair in cases where there is a single religion with the strongest claim to constitutional recognition based on the size of its population within society and the societal contributions of its members, i.e. the ways in which its members have contributed to the country's cultural, political, and economic landscapes over the past decades if not centuries. ${ }^{5}$ Under these conditions, mono-recognition

\footnotetext{
${ }^{3}$ For more elaborate discussions, see e.g. Laborde (2015), Koppelman (2006), and Leiter 2013).

${ }^{4}$ I will say more about when these reasons might be overridden in the final section.

${ }^{5}$ Assuming that these features are relevant in determining the strength of such claims, as seems plausible. All other things being equal, it looks like a religion with, say, thee million members in society has stronger claims to constitutional recognition than a religion with only three hundred members, just as a long-standing religion whose members have heavily shaped the society's culture, economy, and political landscape appears to have stronger claims than a religion of recent immigrants who have collectively contributed much less within these areas.
} 
might be understood to be at least as defensible as forms of plural recognition given that adopting the latter type of religious establishment would mean that the religion with the strongest claim to constitutional recognition would be recognized on a par with religions with weaker claims to constitutional recognition and potentially much weaker ones. For example, it would mean that Anglicanism in England and Lutheranism in Denmark would be given the same amount of constitutional recognition as minority religions such a Hinduism and Islam that have much smaller populations and that are relatively new to these societies. The problem with this, our critics may say, is that it fails to show equal moral concern to citizens by giving per capita less weight to the presence and societal contributions of members of religions with the strongest claim to constitutional recognition than is given to the presence and societal contributions of members of religions with weaker claims. Even when denying constitutional recognition to religions with weaker claims is also problematic as it does not give any weight to their members' presence and societal contributions, our critics might argue that this is not a worse evil and, correspondingly, that mono-recognition is at least as defensible as plural recognition.

The problem with this argument is that it ignores the fact that, unlike synchronic plural recognition which recognizes multiple religions simultaneously, diachronic plural recognition can do justice to differences in religions' entitlements to constitutional recognition by recognizing them for different durations. In England, for instance, the Anglican Church could be constitutionally recognized for five months of the year, Catholicism for two months, Islam for one month, Hinduism for two weeks, and so on. ${ }^{6}$ In so doing, states avoid the abovementioned evils of giving religions either too much constitutional recognition or too little constitutional recognition.

To be sure, for a religion to be constitutionally recognized will be meaningful only insofar as it is recognized for a minimum duration. Were a religion to be constitutionally recognized for a mere hour, say, this would clearly be too short. What is important for our purposes is that within societies with mono-recognition, there usually appears to be at least one unrecognized religion with a claim to constitutional recognition that is strong enough to entitle it to a meaningful amount of recognition-time. ${ }^{7}$ In order to bring this out, notice that for a religion to be entitled to one day of constitutional recognition per year based wholly on its population size - which seems a meaningful amount given that it is the same unit that is successfully used for birthdays, various holidays, and commemorative days such as Martin Luther King Day - its members need to comprise a mere $0,27 \%$ of the country's population insofar as all citizens adhere to some religion and even less if a proportion of them does not. When we consider that the large majority of countries have religious minorities whose populations well exceed this percentage (Pew Research Center 2012) and that these groups have generally been present within society for decades if not centuries (a period during which their members have ordinarily made significant societal contributions), ${ }^{8}$ it looks exceedingly rare for mono-

\footnotetext{
${ }^{6}$ Whilst Alan Patten does not defend forms of temporal accommodation for different religions and cultures, he does provide a theory of multiculturalism that is pro-rated in that the amount of state support that different religions and cultures are due is based on the size of their populations. See Patten (2014).

${ }^{7}$ Notice that when religions lack strong enough claims to be entitled to the minimum amount of meaningful recognition-time, denying them constitutional recognition need not be unfair and might be necessary in order to avoid a proliferation of state religions.

${ }^{8}$ Even when any negative contributions that they have made should be taken into account as well, it is dubious whether religious minorities will have typically caused significantly more harm than religious majorities.
} 
recognition to be justified on grounds that only one religion within a multi-religious society is entitled to a meaningful amount of recognition-time.

In fact, such scenarios become more unlikely still when we take into account a third variable that seems relevant for determining the strength of a religion's claim to constitutional recognition, namely any injustices that its members have suffered at the hands of the state or the wider society and in some cases continue to suffer. For a paradigmatic example of such an injustice, one might think of a case where a state has reduced the population of a particular religion by having organized a pogrom against its members. However, even when no such large-scale violence was committed, widespread discrimination against the members of a specific religion might still have prevented, and sometimes continues to prevent, people from contributing as much to society as they would have been able to contribute otherwise/would be able to contribute otherwise. Under such conditions, it would be unfair to make the amount of recognition-time that is granted to a religion depend wholly upon the size of its population and upon the societal contributions of its members given that if the relevant injustices had not occurred/did not occur, the religion in question would score higher along these dimensions, which suggests that weight needs to be added to its recognition-claim. Since it is usually religious minorities who have suffered disproportional amounts of injustice at the hands of the state and/or the wider society, this then provides further grounds for thinking that there are few, if any, cases where mono-recognition is justified simply because no more than one religion within society is entitled to a meaningful amount of recognition-time.

\section{Objections and Some Rejoinders}

\subsection{Symbolic Recognition and the Scope of Fairness}

At this point, two objections need to be addressed. One says that I am wrong in thinking that mono-recognition is less fair than diachronic plural recognition by virtue of giving one religion a monopoly upon constitutional recognition. On this view, at least when the recognition that is granted is wholly symbolic, which rules out e.g. subsidies for clergy salaries and for the maintenance of places of worship, there cannot be unfairness in refusing it to all but one religion. The reason for this, the objection continues, is that such recognition is not objectively or inherently valuable and only things that are objectively or inherently value can be subject to principles of fairness.

Some might respond to this objection by rejecting the claim that wholly symbolic religious establishment lacks objective or inherent value. Whether this is correct or not, I want to suggest that even if we accept this premise, it does not follow that decisions about which religions are constitutionally recognized fall outside the purview of principles of fairness. ${ }^{9}$ To illustrate this, consider a family with young triplets. Every time this family goes somewhere by car, the children Adam, Bernhard, and Chris argue over who is allowed to sit in the middle of the back of the car. The parents are puzzled by this as sitting in the middle is not objectively or inherently valuable. On the contrary, because the middle seat offers less space and has no adjacent door to lean against, the objective or inherent value of sitting in the middle is lower than that of occupying one of the two side-seats. (Suppose arguendo that that none of the children suffer from car sickness, which is a reason for some individuals to want to sit in the

${ }^{9}$ I develop this point in more detail in De Vries (Forthcoming). 
middle as looking through the front window protects them from feeling sick.) Still, insofar as the parents only ever allow, say, Adam to sit in the middle, it looks like Bernhard and Chris are being treated unfairly unless the parents have good reasons for giving Adam a monopoly upon the middle seat. Likewise, even if there is nothing objectively or inherently valuable about religious establishment, when a state constitutionally recognizes the religion of a group of citizens A but not the religion of another group of citizens B and at least some members of B want their religion to be constitutionally recognized, it seems that the state is treating its citizens unfairly unless it has good reasons for refusing constitutional recognition to B's religion.

A critic might accept this but argue that within societies with mono-recognition, members of unrecognized religions do no actually desire constitutional recognition of their religion. To the extent that this is correct and these individuals need to have such desires in order for it to be unfair to deny constitutional recognition to their religion, it follows that it cannot be unfair for contemporary states to maintain their systems of mono-recognition.

Whilst I am unaware of any survey data on this issue, there is reason for doubting the empirical premise of this argument. When we consider the significance that is commonly attached to even largely symbolic forms of state recognition - for example, although civil partnerships gave British same-sex couples virtually all the same legal rights as married heterosexual couples had before same-sex marriages were legalized in 2013, being able to marry still mattered deeply to many gays and lesbians - along with the fact that in almost all societies with mono-recognition, thousands if not millions of people adhere to religions other than the state religion, one might expect that there are usually some citizens who want the state to constitutionally recognize their unrecognized religion. Further support for this supposition is provided by the fact that when religious groups seek rights and privileges that are already held by other religious groups within society, their members often do not simply care about the tangible benefits involved, as important as these may be to them. In many cases, they also care about the symbolism of receiving said rights and privileges. Just witness the decision of the German city-state of Bremen to recognize Islamic organizations as religious bodies in 2013, which was a status that Christian organizations and Jewish organizations already enjoyed within its jurisdiction. Whilst this decision gave local Muslims various new legal entitlements, including the right to take days off on Islamic holidays and the right to bury their dead according to their religious precepts (i.e. without a coffin), this was not the only reason why it was welcomed. As Erol Pürlü, a spokesperson for the German Muslim Coordination Council put it, the decision was also welcomed by the Muslim community because it "sends a clear signal that Islam belongs to Germany" (Deutsche Welle 2013).

So far, I have suggested that within societies with mono-recognition, there is likely to be a proportion of citizens with unrecognized recognition-entitled religions who desire constitutional recognition of their religion. What I want to add here is that even when these citizens are not present, it seems that insofar as they would be present if (more) citizens with unrecognized religions were to contemplate a scenario in which their religion is constitutionally recognized, this is already enough to render existing systems of mono-recognition morally problematic. To see this, notice that denying its sufficiency would mean, among other things, that when citizens with unrecognized recognition-entitled religions have never imagined a world in which their religion is constitutionally recognized because the decade- if not century-long constitutional recognition of another religion has made its sole established status look natural, this could justify existing systems of mono-recognition even when some of these individuals would want their religion to be constitutionally recognized if they were to imagine such a world. 
If I am right in thinking that this is an implausible implication and, consequently, right in thinking that such counterfactual desires for constitutional recognition carry normative weight, then this provides additional support for the notion that diachronic plural recognition is fairer than mono-recognition within multi-religious societies. The reason for this is that there exists a high probability that at least some citizens within these societies would want their unrecognized recognition-entitled religion to be constitutionally recognized upon reflection. Perhaps the easiest way of showing this is to point out that few individuals seem to have ever contemplated the possibility of plural recognition within their society given that there are no contemporary examples of either synchronic plural recognition or diachronic plural recognition (indeed, I am the first to set out the idea of diachronic plural recognition in this article). Once we take this into account along with the already mentioned fact that many people within contemporary societies are sensitive to unequal distributions of state recognition, it becomes highly plausible that a proportion of citizens with unrecognized recognition-entitled religions would want their religion to be constitutionally recognized alongside the current state religion and possible other religions, whether synchronically or diachronically.

\subsection{Prorated Recognition Versus Non-Prorated Recognition}

The other objection does not challenge my claim that, ceteris paribus, diachronic plural recognition ought to be favored over mono-recognition within multi-religious societies. Instead, it challenges my claim that this type of religious establishment ought to reflect differences in the strength of religions' entitlements to constitutional recognition by recognizing them for different amounts of time. Critics of such pro-rated recognition may point to how the Presidency of the Council of the European Union is rotated among EU member-states at equal intervals of six months regardless of the size of their populations, their contributions to the EU budget, and so on. ${ }^{10}$ Whilst this model has not been immune from criticism (e.g. Vanhoonacker et al. 2011), those who object to it rarely do so on grounds that they consider it to be unfair that EU-member states hold the presidency for equal amounts of time. However, if this system is not unfair, then it might be said that neither can a version of diachronic plural recognition be under which religions are recognized for the same duration.

My rejoinder is that even if we grant the premise that the rotating Presidency of the EU Council is not unfair, which some might wish to question, there is a relevant asymmetry between it and a version of diachronic plural recognition that allows for differences in recognition-time. Since the EU is a union of sovereign states, ${ }^{11}$ there is at least something to be said for giving equal presidency-time to its member-states. However, since states consist of collections of individual citizens to whom they owe equal moral concern, giving equal recognition-time to religions irrespective of the strength of their claims to constitutional recognition looks much harder to justify. To see this, notice that if I am right that some religions have stronger claims to constitutional recognition than other religions because of the fact that they have more adherents; the fact that their adherents have contributed more to society; and/or the fact that their adherents have suffered greater injustice at the hands of the state and/or the wider society, then by granting the same amount of recognition-time to religions, states are treating the adherents of religions with stronger claims to constitutional recognition as if their presence and societal contributions along with any injustices suffered by

\footnotetext{
${ }^{10} \mathrm{I}$ am indebted to an anonymous reviewer for suggesting this case.

${ }^{11}$ This is true even if it is acquiring some federation-like characteristics.
} 
them matter less as the presence and societal contributions of, and possible injustices suffered by, the adherents of religions with weaker claims.

\section{Diachronic Plural Recognition vs Non-Recognition of any Religion}

I have argued that when the choice is between mono-recognition and diachronic plural recognition, there are strong reasons for favoring the latter. In particular, I argued that diachronic plural recognition is fairer than mono-recognition by not giving any religion a monopoly upon constitutional recognition. At the same time, I suggested that because religions tend to have unequal claims to constitutional recognition, diachronic plural recognition is fairer than synchronic plural recognition by allowing religions with stronger claims to receive more recognition-time than religions with weaker claims. The main point that I want to make in this section and the next is that, within many multi-religious societies, there are also strong reasons for favoring diachronic plural recognition over a system whereby no religion is constitutionally recognized - call this 'non-recognition of any religion' for short. Along the way, several additional reasons will be identified for favoring diachronic plural recognition over synchronic plural recognition.

\subsection{Protection from Radical Secularism and Religious Extremism}

Two pro-establishment arguments have been proposed recently by David Miller. Focusing upon mono-recognition, Miller (2019) believes that religious establishment should come with duties for established religions to give religion in general a voice in public debates and to protect it against the forces of "radical secularism", which are understood to be manifested in e.g. head scarf-bans in public buildings. When such duties are performed, he thinks that believers of all stripes benefit from the presence of an established religion, including members of (vulnerable) religious groups whose religion is not constitutionally recognized.

In fact, Miller's view is that even agnostics and atheists draw net benefits from this kind of ecumenical establishment as he goes on to suggest that it has a moderating influence upon established religions. The idea here is that when established religions are expected to represent the interests of, and collaborate with, other religions - he gives the example of how the Church of England is expected to engage in inter-faith dialogue and to involve members of other religions in official events such as parliamentary inaugurations and state funerals - they are disincentivized from espousing extreme views as to do so would compromise their ability to fulfil these tasks. According to Miller, this in turn has the effect that

The public voice of an established church is likely to be moderate, ecumenical, and closer in substance to secular discourse. You don't find spokespersons for these churches arguing that evolution is nonsense or that Jews must seize the whole of Jerusalem to hasten the second coming of Christ. A rational atheist, therefore, must weigh the comparative advantages and disadvantages of establishment and disestablishment, on the assumption that the latter won't mean the end of religion itself or its disappearance from the public sphere (Miller 2019).

What is apposite for us is that if it is true that Miller's ecumenical establishment helps to protect religious interests from radical secularism and to prevent extremism within the ranks of 
established religions, then given that these effects appear to be valuable, this would provide reasons for favoring this type of establishment over non-recognition of any religion. However, since an investigation into these ostensible effects is well beyond this article's scope, I should note that whilst my case for diachronic plural recognition would be strengthened by their existence, it does not depend upon their existence as I will provide independent arguments for diachronic plural recognition within the next section.

Now Miller himself is doubtful as to whether plural recognition can fulfil the ecumenical functions just mentioned and, consequently, have the instrumental benefits under consideration.

The idea of establishment involves recognising the church's special authority to speak on religious matters, but also [...] giving it the responsibility to serve all citizens in an inclusive way. It's unclear how this could be done in the case of more than one institution (Miller 2019).

Some might disagree with the notion that only a single religion can fulfil this inclusive role. Even if there are limits to how many religions can fulfil it, they may argue that it is possible for two or three religions to do so and possibly even more. What I want to suggest here is that even if this is mistaken, this merely shows that synchronic plural recognition is unfit for purpose, not diachronic plural recognition. The reason for this is that at no point in time would more than one religion be constitutionally recognized under the proposed diachronic variant.

Admittedly, state religions will be able to discharge the abovementioned ecumenical functions only if they are constitutionally recognized for a meaningful amount of time - for them to be recognized for a mere hour, say, will be of little use. Whilst a discussion of precisely how much recognition-time is needed would take us too far afield as it would require us, inter alia, to specify in more detail what these functions involve (which Miller does not do in his article), what matters for us is a point that I made in the penultimate section, namely that such thresholds can be built into a system of diachronic plural recognition. One way of doing so is to exclusively recognize religions with strong enough claims to constitutional recognition to be entitled to the requisite amount of recognition-time based on their population size, their members' societal contributions, and any injustices that their members have suffered at the hands of the state and/or the wider society. Another approach is to recognize some religions for longer periods than is warranted based on the strength of their claims to constitutional recognition so that they are recognized for the requisite duration. Although such an approach is unfair in some respects as it discounts other religions' claims to constitutional recognition to a certain degree, it should be noted that refusing constitutional recognition to religions that have some claim to such recognition but not one that is strong enough to entitle them to the requisite amount of recognition-time is also unfair in certain respects as it means that the claims of these religions do not translate into any recognition-time. At least when religions are not too far removed from the threshold, then, it might be argued that it is morally permissible if not required for states to constitutionally recognize them for the requisite duration.

\subsection{Communicative Value}

Having looked at two potential benefits of religious establishment, namely the provision of protection against radical secularism and the provision of protection against religious extremism, I now want to suggest that there are communicative reasons for favoring diachronic plural 
recognition specifically over non-recognition of any religion when there are religious groups within society that are marginalized in that their members suffer significantly higher levels of discrimination and hostility than the members of other religious and non-religious groups. To focus attention, consider the following expressions of anti-Islamic sentiments and violence that have occurred in Germany over the past years:

- In the East-German city of Dresden, demonstrations of anti-Islam movement Pegida attracted 10,000 s of people during the mid-2010s (BBC 2015).

- In 2017 alone, 950 violent attacks were committed against Muslims and against Islamic institutions such as mosques according to statistics from the Department of Interior (Zeit Online 2018).

- More recently, a far-right extremist killed nine people in two shisha-bars in the WestGerman city of Hanau, an attack that is widely believed to have been motivated by Islamophobic motives (Deutsche Welle 2020).

- In an interview with the German tabloid Bild in 2018, interior minister Horst Seehofer stated that "Islam does not belong to Germany" (Süddeutsche Zeitung 2018).

- Anti-immigrant and anti-Islam party Alternative Für Deutschland [Alternative for Germany] is currently the largest opposition party in the national parliament with $12,8 \%$ of the seats. In 2019, the AFD won $27 \%$ of the votes in local elections in Saxony where it finished second just behind the Christian-Democrats (CDU).

Further evidence of the vulnerable position of Muslims within German society is provided by studies into labor market discrimination against this group. For example, in a recent study (Weichselbaumer 2020), 1474 resumes were sent to German firms that were identical except for the fact that some had the native German name 'Sandra Bauer' on them; some the Turkish name 'Meryem Öztürk' but with the same picture as the Sandra Bauer-resumes (in Germany, resumes tend to have pictures); and some the name 'Meryem Öztürk' with again the same picture except for the fact that the woman shown on it wore a headscarf this time. The findings were that whilst Sandra Bauer was invited for an interview in $18.8 \%$ of cases, Meryem Öztürk without a headscarf received an invitation in $13.5 \%$ of cases and Meryem Öztürk with a headscarf did so in only $4.2 \%$ of cases.

Against this socio-political background, there can be little doubt that for Germany to recognize Islam as the sole state religion for certain periods would send a powerful message that this religion belongs to society and, implied by this, its members. This is true at least when each time a new religion is constitutionally recognized under a system of diachronic plural recognition, the state informs the public of this as I assume here it should. Ways of doing so might include, but are not limited to, announcing the new state religion on social media and on public broadcasters; allowing its leaders to play a ceremonial role in state events such as parliamentary inaugurations and state funerals; and displaying its symbols in parliament in the same way that a Christian crucifix is displayed in Quebec's National Assembly.

Why is it important for states to signal the civic inclusion of marginalized religious groups? One reason is that because of the symbolic value that many people attach to the state's actions and inactions, not doing so can easily aggravate discrimination and hostility against their members by making such discrimination and hostility seem legitimate (cf. Waldron 2014). This is the case when the state's unwillingness to send such signals is widely interpreted as reflecting prejudice against these individuals or as expressing simple indifference towards their fate. However, even when no such prejudice or indifference is perceived in such omissions, the 
fact that the state's speech is imbued with symbolic significance means that for governments to publicly affirm the civic inclusion of marginalized religious groups still has the potential to reduce discrimination and hostility against their members by shaping public attitudes (for more about the impact of state speech upon public attitudes and about the importance of the state's role as a propagator of liberal-democratic values, see Brettschneider 2012).

Of course, constitutionally recognizing the religions of marginalized religious groups is not the only way in which states might communicate that these groups belong to society. Other ways of doing so include e.g. speaking out against any unlawful discrimination and violence suffered by their members and imposing strict penalties upon those who are found guilty of such discrimination and violence. In the next section, I will address the objection that my case for diachronic plural recognition is underdetermined; for now, I want to suggest another reason why it is important that states signal the civic inclusion of marginalized religious groups.

According to this reason, sending such signals also matters because it provides their members with assurances that the authorities are on their side and that they are regarded by those in power as full and equal citizens. Having such assurances is not just valuable because it may offer peace of mind, though this is a significant benefit. As Adam Omar Hosein (2018) has pointed out, it also helps people to take advantage of their legal rights, especially those that involve direct interaction with government officials. For example, studies from the United States have found that individuals who lack trust in state institutions - as is common among black people within this country as well as among those with Arab, Middle Eastern, Muslim, and South Asian backgrounds - are less likely to report crimes that were committed against them than individuals who do have such trust (Huq et al. 2011; Tyler 2005). (Of course, being assured of the state's commitment to upholding one's rights and liberties will be valuable only if the state actually has this commitment as I assume here it does. When this is not the case, for citizens to believe that they can count upon the state's protection and support when they cannot is not only problematic because of the deception involved, but also because they might end up in dangerous situations as when they wrongly expect law-enforcers to protect them from physical assault.)

\section{Objections and Some Rejoinders}

\subsection{Underdetermination}

As already alluded to, there are ways for states to communicate that marginalized religious groups belong to society that do not involve granting constitutional recognition to their respective religions, which may lead some to argue that my communicative case for diachronic plural recognition is underdetermined. Besides the ones already mentioned, namely speaking out against any unlawful discrimination and violence suffered by their members and imposing strict penalties upon those responsible for such discrimination and violence, one might think, for instance, of designating some of their religious holidays as public holidays; arranging visits between their leaders and the country's president or monarch; and subsidizing schools that are organized around tenets of their faiths.

My response to this objection is that whilst it is true that constitutionally recognizing the religions of marginalized religious groups is not the only way of signaling that these groups belong to society, doing so is a highly effective way. In fact, when we consider that constitutions lay out the fundamental principles of states and carry much symbolic value 
within most countries, there appear to be few ways of sending these signals that are more powerful and unambiguous. This power is amplified further by the fact that under diachronic plural recognition, constitutionally recognized religions are the sole state religion for a given period as opposed to being merely one state religion among many as they are under synchronic plural recognition. For just as celebrating the birthdays of all members of a family on the same day diminishes the communicative value of each person's birthday as no family member would be receiving special attention, so for a state to constitutionally recognize several religions simultaneously - in some cases tens if not hundreds of religions - is bound to reduce the communicative value of each religion's recognition as no religion would ever stand in the limelight.

Besides being a particularly potent way of signaling the civic inclusion of marginalized religious groups, it should be noted that constitutionally recognizing the religions of these groups is a relatively cheap and therefore efficient signaling tool as well. Apart from the fact that constitutionally recognizing a religion does not impose any financial costs in and of itself, communicating its established status need not be expensive. I have mentioned that it can already be done by e.g. posting messages on social media and making announcements on public broadcasters. But if these observations are correct, then whatever other measures states could and perhaps should take in order to signal that marginalized religious groups belong to society, they seem to have strong reasons for constitutionally recognizing their religions and for doing so under a system of diachronic plural recognition specifically.

\subsection{Preferences for Non-Recognition}

Another objection maintains that diachronic plural recognition, among other forms of religious establishment, fails to pay heed to the preferences of citizens who do not want the state to constitutionally recognize any religion, who might include many atheists. There are two things to be said in response. First, insofar as these preferences are motivated by the belief that such recognition unfairly favors the interests of believers over those of individuals with secular (i.e. non-religious) comprehensive doctrines, I should repeat a point made at the outset, namely that I am not precluding the possibility that any constitutional recognition that is granted to religions might need to be extended to secular comprehensive doctrines such as Humanism and Confucianism. Whether this is the case will depend on whether religions have features that render it morally permissible if not required to treat them differently in this area.

However, and this brings me to the second point, insofar as the objection is that diachronic plural recognition does not accommodate the preferences of citizens who categorially oppose constitutional recognition of all religions or of certain specific religions (which might include their own religion), I do not think that this is a convincing objection. For as long as the recognized religions are both compatible with liberal democracy and entitled to constitutional recognition under the proposed criteria, as I assume in this article they are, it does not seem reasonable to complain about the fact that they are constitutionally recognized as such even if it is reasonable to object on distributive grounds to any tangible benefits that might come with this status. In order to bring this out, notice that under the model of diachronic plural recognition defended here, for a religion to be constitutionally recognized does not mean that the state regards it as the true faith or as a faith that is otherwise superior to other faiths within society, which would have the implausible implication that whenever a new religion becomes the state religion, it would gain the status of the true or otherwise superior faith. All that the conferral of such recognition communicates is that the recognized religion has a legitimate 
place within society and, implied by this, that its adherents are full and equal citizens, which is the same message that is sent when, for instance, states recognize certain holidays of minority religions as national holidays. Since this is a perfectly reasonable message to send and, I have argued, a practically important one when the adherents of some religions face comparatively high levels of discrimination and hostility (see the previous section), it is hard to see how one can have a morally valid complaint against it.

\subsection{Neo-Establishment}

Some might accept this but say that it remains odd to introduce diachronic plural recognition within societies where there is no pre-existing religious establishment. Consider Germany where several religions are legally recognized as eligible for receiving a state-collected religious tax [Kirchensteuer] but where there are no state religions. Even if I am right that constitutionally recognizing Islam under a system of diachronic plural recognition would have significant benefits within this country given the levels of discrimination and hostility to which local Muslims are exposed (see the previous section), creating a system of religious establishment ex nihilo may strike many as an unorthodox measure.

Whilst introducing religious establishment would certainly be unorthodox in today's world, I do not think that this is a compelling reason against it as such. Consider the abolition of slavery and the enfranchisement of women; although these policies were highly unorthodox at the time that they were introduced, their unorthodox character did not seem to have provided even pro tanto reasons against their enactment. What these and other similar cases suggest is that merely pointing out that it would be unusual for contemporary states to introduce religious establishment is not enough to argue against it, at least not when there are good reasons for its introduction.

Another thing to mention here is that even if adopting diachronic plural recognition only made sense in societies where religious establishment already exists, the findings of this article would remain relevant given that many of the circa $20 \%$ of countries with mono-recognition are home to marginalized religious groups that do not have their religion constitutionally recognized (Pew Research Center 2017, 2019). If my arguments are sound, then these countries would still have reasons for changing to a system of diachronic plural recognition.

\section{Concluding Remarks}

I have argued that diachronic plural recognition is fairer than mono-recognition and synchronic plural recognition respectively, before arguing that there are communicative reasons within many societies for favoring this type of religious establishment over both non-recognition of any religion and synchronic plural recognition. To avoid confusion, I should end by noting that this does not mean that introducing diachronic plural recognition will always be justified within these societies. Cases where it might not be include ones where abandoning existing systems of mono-recognition will be experienced by many citizens as a threat to their religion and/or culture and lead to serious social instability (e.g. riots) as well as ones where introducing any form of religious establishment will cause such instability because many citizens are militant atheists. Still, if I am right that diachronic plural recognition has important benefits for marginalized religious groups, then in large parts of the world, the reasons for adopting this type of religious establishment are not easily overridden. 
Acknowledgments I thank the participants of the 'Multiculturalism, Nationalism, Religions and Secularism' conference at Bristol University for helpful comments. Thanks are also due to the two anonymous reviewers.

Funding Open Access funding provided by Umea University. My research is supported by an international postdoctoral fellowship (2018-00679) from the Swedish Research Council.

\section{Compliance with Ethical Standards}

Declaration of Conflicting Interests No conflict of interests.

Open Access This article is licensed under a Creative Commons Attribution 4.0 International License, which permits use, sharing, adaptation, distribution and reproduction in any medium or format, as long as you give appropriate credit to the original author(s) and the source, provide a link to the Creative Commons licence, and indicate if changes were made. The images or other third party material in this article are included in the article's Creative Commons licence, unless indicated otherwise in a credit line to the material. If material is not included in the article's Creative Commons licence and your intended use is not permitted by statutory regulation or exceeds the permitted use, you will need to obtain permission directly from the copyright holder. To view a copy of this licence, visit http://creativecommons.org/licenses/by/4.0/.

\section{References}

América Economía (2013) Cerca de 50\% de los costarricenses quiere que su país sea un Estado laico. March 31, 2013. https:/www.americaeconomia.com/politica-sociedad/politica/cerca-de-50-de-los-costarricensesquiere-que-su-pais-sea-un-estado-laico. Accessed 14 Nov 2020

BBC (2015) Why are thousands of Germans protesting and who are Pegida? BBC Newsbeat (blog). January 13, 2015. http:/www.bbc.co.uk/newsbeat/article/30694252/why-are-thousands-of-germans-protesting-andwho-are-pegida. Accessed 14 Nov 2020

Brettschneider C (2012) When the State speaks, what should it say?: How democracies can protect expression and promote equality. Princeton University Press, Princeton

Cohen JL (2013) Political religion vs non-establishment: reflections on 21st-century political theology: part 1*. Philos Soc Critic 39(4-5):443-469. https://doi.org/10.1177/0191453713479100

De Vries, Bouke. Forthcoming. "Five Arguments Against Single State Religions." Ethnicities

Deutsche Welle (2013) Islam takes another step to German recognition. January 29, 2013. https://www.dw.com/ en/islam-takes-another-step-to-german-recognition/a-16556956. Accessed 14 Nov 2020

Deutsche Welle (2020) After Hanau Attack, Germany steps up protection of Muslims | DW | 21.02.2020. DW.COM. February 21, 2020. https:/www.dw.com/en/after-hanau-attack-germany-steps-up-protection-ofmuslims/a-52470189. Accessed 14 Nov 2020

Hosein AO (2018) Racial profiling and a reasonable sense of inferior political status. J Polit Philos 26(3):e1-20. https://doi.org/10.1111/jopp.12162

Huq AZ, Tyler TR, Schulhofer SJ (2011) Why does the public cooperate with law enforcement? The influence of the purposes and targets of policing. Psychol Public Policy Law 17(3):419-450. https://doi.org/10.1037/ a0023367

Ingolfsson B (2015) Fleiri Hlynntir Aðskilnaði Ríkis Og Kirkju. RÚV. October 23, 2015. https://www.ruv.is/ frett/fleiri-hlynntir-adskilnadi-rikis-og-kirkju. Accessed 14 Nov 2020

Kellner P (2013) Ye of little faith. Prospect. December 12, 2013. https:/www.prospectmagazine.co.uk/magazine/ church-of-england-drop-religion-take-up-politics. Accessed 14 Nov 2020

Koppelman AMM (2006) Is it fair to give religion special treatment? Univ Ill Law Rev 2006(3):571-603

Laborde C (2015) Religion in the law: the disaggregation approach. Law Philos 34(6):581-600

Leiter B (2013) Why tolerate religion? Princeton University Press, Princeton

Maclure J, Taylor C (2011) Secularism and freedom of conscience. Harvard University Press, Cambridge

Miller D (2019) What's wrong with religious establishment? Crim Law Philos, June. https://oi.org/10.1007/ s11572-019-09496-7

Nussbaum MC (2011) Perfectionist liberalism and political liberalism. Philos Public Aff 39(1):3-45. https://doi. org/10.1111/j.1088-4963.2011.01200.x 
Patten A (2014) Equal recognition: the moral foundations of minority rights. Princeton University Press, Princeton

Pew Research Center (2012) The global religious landscape a report on the size and distribution of the world's major religious groups as of 2010. 2012. https://assets.pewresearch.org/wp-content/uploads/sites/11/2014/ 01/global-religion-full.pdf. Accessed 14 Nov 2020

Pew Research Center. (2017). Many Countries Favor Specific Religions Officially or Unofficially (pp. 1-36). Pew Research Center, Washington DC. https:/www.pewforum.org/2017/10/03/many-countries-favorspecific-religions-officially-or-unofficially/. Accessed 14 Nov 2020

Pew Research Center. (2019). A Closer Look at How Religious Restrictions Have Risen Around the World (pp.1-125). Pew Research Center, Washington DC. https://www.pewforum.org/2019/07/15/a-closer-look-athow-religious-restrictions-have-risen-around-the-world/. Accessed 14 Nov 2020

Sandberg R (2011) Law and religion. Cambridge University Press, Cambridge

Süddeutsche Zeitung (2018) Seehofer: Der Islam gehört nicht zu Deutschland. sueddeutsche.de, 2018, sec. politik. https://www.sueddeutsche.de/politik/integration-seehofer-der-islam-gehoert-nicht-zu-deutschland-1. 3908644. Accessed 14 Nov 2020

Tyler TR (2005) Policing in black and white: ethnic group differences in trust and confidence in the police. Police Q 8(3):322-342. https://doi.org/10.1177/1098611104271105

Vanhoonacker S, Pomorska K, Maurer H (2011) The Presidency in EU external relations: who is at the helm? Politique Européenne 35(3):139-164

Waldron J (2014) The harm in hate speech. Reprint edition. Cambridge: Harvard University Press

Weichselbaumer D (2020) Multiple discrimination against female immigrants wearing headscarves. ILR Rev 73(3):600-627. https://doi.org/10.1177/0019793919875707

Zeit Online (2018) Muslime in Deutschland: Mindestens 950 islamfeindliche Straftaten im Jahr 2017. Die Zeit, March 3, 2018, sec. Gesellschaft. https://www.zeit.de/gesellschaft/zeitgeschehen/2018-03/muslimedeutschland-islamfeindlichkeit-angriff-bundesinnenministerium. Accessed 14 Nov 2020

Publisher's Note Springer Nature remains neutral with regard to jurisdictional claims in published maps and institutional affiliations. 